BRITISH PUBLIC ATTITUDES TO NUCLEAR DEFENCE 


\section{British Public Attitudes to Nuclear Defence}

Peter M. Jones

Lecturer in Politics

University of Reading

and

Gordon Reece

Senior Lecturer in Engineering Mathematics

University of Bristol

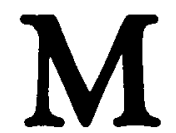


(C) Peter M. Jones and Gordon Reece 1990

All rights reserved. No reproduction, copy or transmission of this publication may be made without written permission.

No paragraph of this publication may be reproduced, copied or transmitted save with written permission or in accordance with the provisions of the Copyright, Designs and Patents Act 1988, or under the terms of any licence permitting limited copying issued by the Copyright Licensing Agency, 33-4 Alfred Place. London WC1E 7DP.

Any person who does any unauthorised act in relation to this publication may be liable to criminal prosecution and civil claims for damages.

First published 1990

Published by

THE MACMILLAN PRESS LTD

Houndmills, Basingstoke, Hampshire RG21 2XS

and London

Companies and representatives

throughout the world

British Library Cataloguing in Publication Data

Jones, Peter M.

British Public Attitudes to Nuclear Defence.

1. Great Britain. Nuclear Weapons. Attitudes of Public

I. Title II. Reece, Gordon

$355.8^{\prime} 25119^{\prime} 0941$

ISBN 978-0-333-52204-2

DOI 10.1007/978-1-349-20672-8

ISBN 978-1-349-20672-8 (eBook) 


\section{Contents}

Introduction vii

Statistical Summary 1

1 Patterns of Belief: Comparisons with Previous Surveys 15

2 New Developments in British Attitudes to Nuclear Weapons 41

3 The Political Parties, Nuclear Weapons and the Future 62

$\begin{array}{ll}\text { The Statistics } & 95\end{array}$

$\begin{array}{ll}\text { Index } & 200\end{array}$ 


\section{Introduction}

In late 1985 it was discovered that there were a number of groups working on the possibility of commissioning a survey of British public attitudes towards nuclear weapons. Rather than duplicate the effort and reduce the effectiveness of the survey, it was decided to pool resources and work together to produce the best possible survey. To this end a research team was established. This research team consisted of Peter Jones, a lecturer in Politics at Reading University who acted as treasurer: he is responsible for the editing of the commentary section of the book in general and for chapter 3, which discusses the political impact of the survey; Carol Freeman, a former lecturer who acted as research group co-ordinator: she is responsible for chapter 2, which discusses the changing national mood; Roger Harrison, a lecturer at the Open University who is responsible for chapter 1 , which places the survey in a general context; and Gordon Reece, a lecturer at Bristol University who acted as the group's statistician and is responsible for preparing and editing the Statistical Section. Other people were co-opted onto the team from time to time to assist in specific matters. This book is the result of the efforts of this research team.

The team was encouraged to pursue the idea of a survey of British public attitudes towards nuclear weapons by the success of the research work carried out by the Public Agenda Foundation, which produced, in 1984, a series of briefing books in time for the American presidential election. One of these books was entitled Voter Options on Nuclear Arms Policy ${ }^{1}$ and it is believed by many people to have played a significant part in moulding the thinking of President Reagan and his fellow Republicans about policy on arms control and nuclear weapons. This team cannot claim such a laudable intention, but it is to be hoped that this book will inform debate both within political parties and amongst those interested in matters concerned with British defence policy by giving some data on British public attitudes towards nuclear weapons.

The survey of popular attitudes was undertaken in early August 1987 when Omnimas interviewed approximately 2400 respondents throughout the mainland of the United Kingdom ${ }^{2}$ and the results represent not just a snapshot of public opinion at that particular time but, as the Statistical Section clearly shows, they also give a large amount of sociological data as well as some insight into why many people hold the views that they do. For those interested in developing the defence debate beyond the rather sterile 'dialogue of the deaf' between such organisations as CND and 'Peace Through NATO' and the sloganised one-dimensional inter-party 'debate' on defence, it is essential to find out what people think and what they 
know. The subject of nuclear weapons inspires one of several reactions in most people: fear; moral outrage; indifference; and concern. Such reactions are often based on prejudice and frequently accompanied by a substantial lack of knowledge. In a democracy, before we can begin to address the question of what to debate about, we need to know what is the level of public knowledge on the question to be debated. This book is designed to provide an answer to that question. It will become clear to the reader that not all the authors agreed on the interpretation of the data, nor would the team claim that the interpretations given here are the only ones capable of being drawn from this material. We hope to stimulate others to develop the work we have begun and, if funding is available, to repeat the survey at regular intervals.

Before the Omnimas survey was carried out, some qualitative research was undertaken in order to identify the sort of questions it was possible to ask and from which it might be possible to obtain reasonably informed responses. The qualitative research was conducted in the form of small groups of between eight and ten people generally from the $\mathrm{C} 1$ or $\mathrm{C} 2$ class group. Leadership of these small group discussions was in the hands of a person skilled in this kind of work and each group was attended by at least one member of the research team. This was interesting, enlightening and, sometimes, highly amusing. One group member thought that 'like the gas bill', a nuclear war would come at the most inconvenient time; a view which was capped by the remark that it was presumed that what was meant was that it would come just after the gas bill had been paid! On a more serious note it became clear during the course of the qualitative research that a number of questions frequently asked in surveys of opinion on nuclear policy conveyed little real meaning to the respondents. One finding, for example, was that very few people seemed to be aware of the difference between Polaris and Trident, often believing that the latter was simply a direct replacement for the former and being unaware of the enormous increase in nuclear firepower that Trident represents. Nor was there much real understanding of the concept of the Strategic Defence Initiative: one group member referred to 'President Reagan's UDI in space' during a discussion of space weapons. Another broad area of interest which proved equally inappropriate was the question of the value of different kinds of nuclear weapons. Whilst most people had heard of the SS20s and Cruise missiles, few seemed aware of their purpose or function. Knowledge on this question seemed to vary from north to south: those in the north of equal educational and social position to those in the south seemed generally more concerned about nuclear questions and better informed. One possible explanation of this phenomenon might be that the local authorities in those areas have been more assiduous in distributing information about nuclear weapons to their inhabitants. It became clear, therefore, that several of the issues which apparently would have been worth developing were inappropriate for a mass survey. 
Once the qualitative research had been undertaken the final format of the questionnaire was determined by the research group. It is now clear that the phraseology of some questions could have been improved. It was decided that the answers to each question of the survey would be correlated with the others. As a consequence, the research team was presented with a final report from Omnimas which ran to over two hundred pages of statistics! The basic findings of the survey were first published in December 1987 in time for the Moscow Summit between President Reagan and General-Secretary Gorbachev which resulted in the INF agreement. Most of the detailed statistics are reproduced for the first time in the Statistical Section of this book. It should be pointed out that the research team concluded that some of the questions asked in the survey resulted in responses that were far less interesting than had been anticipated. Nevertheless, the results of the survey are extremely informative about a wide range of aspects of British public attitudes towards nuclear weapons. ${ }^{3}$

Before the reader turns to the commentaries which make up the first section of the book, I believe that a few general comments on the findings are appropriate. In his book on Public Opinion and Foreign Policy, ${ }^{4}$ Professor James Rosenau distinguished between three broad groups of public opinion. The research we have carried out has been concerned with the area of general public opinion. Unlike the Public Agenda Foundation report which also researched into the attitudes of officials and other opinion-formers, this survey does not attempt to assess informed or élite public opinion, although some views of the 'Establishment' might be discerned from a close analysis of the A/B class group and from the readership of the 'quality' press. What is remarkable about the present survey, however, is that there is a far higher degree of consistency displayed by the general public in its attitudes towards nuclear weapons than might have been anticipated. What is equally remarkable is the fact that there appear to be two broad groups of popular opinion: one predominantly optimistic and the other predominantly pessimistic.

In the chapters which follow, the reader will note that there is considerable discussion of the answers to the question in the survey concerned with British Government policy on the use of nuclear weapons and the very low percentage of respondents giving the official position. One possible explanation for this might be that the official position of using nuclear weapons first is seen as being so suicidal that public opinion simply cannot believe that such a position can credibly be held by anyone. An alternative explanation for this finding, as Roger Harrison argues in chapter 1 , could be that the responses to this question were possibly a reflection of what people thought the policy ought to be or what they hoped it would be. Undoubtedly, the survey shows that there are concerns about the future but also a substantial body of support for deterrence as a practical purpose for which nuclear weapons are well suited. This view, as 
Carol Freeman points out in chapter 2, is shared not only by those who believe that Britain should have nuclear weapons but also by a substantial number of those who oppose British possession of nuclear weapons. The political implications of both these points are significant both for the government and the opposition parties and this is discussed by Peter Jones in chapter 3.

A second major finding of the study is that, whereas a decade ago there was one group on the left blaming the United States for the problems of the nuclear age and a second one on the right blaming the Soviet Union, now there is one group which sees both superpowers as being equally to blame. This is accompanied by a clear belief that Britain has very little role to play in the international nuclear debate.

A third major finding is that there is less expectation of a nuclear war between the superpowers, but the chances of nuclear weapons being used by accident, by a madman or in a conflict in the Third World have greatly increased. This leads to an interesting dichotomy of view: the general public still retains substantial confidence in the effectiveness of deterrence; but at the same time is increasingly concerned at the prospect of nuclear war breaking out because of a breakdown of deterrence or as a result of some person or event not controllable by deterrence. Thus, nuclear weapons are seen as an international problem which requires an international solution. This is an important message for all the political parties in Britain today because none of them are seen to be addressing this particular concern.

Finally, we should like to record our thanks to those who gave us their generous assistance, which made it possible for the research to be undertaken. The research was funded by means of a grant from GarfieldWeston Foundation and the Joseph Rowntree Charitable Trust, without whose generous support it would not have been possible to carry out the survey on which most of the present volume is based. The authors are also grateful to Martin Schlaeppi of Taylor Nelson Monitor for his help with the drawing up of the survey and to Omnimas for carrying it out on our behalf. We are also grateful for all the help and advice given to us during the preparatory stages of the research, but final responsibility for the survey and the conclusions published in the following chapters remains in the hands of the authors.

\section{Notes}

1. Voter Options on Nuclear Arms Policy (New York: Public Agenda Foundation, and The Centre for Foreign Policy Development at Brown University, Providence, Rhode Island, 1984).

2. The significance of such a large sample is that the degree of statistical error is 
reduced to a very small percentage. This point is developed in the introduction to the Statistical Section.

3. The survey questions and the general responses are reprinted in the Statistical Summary which follows this Introduction and are discussed in the introduction to the Statistical Section.

4. James N. Rosenau, Public Opinion and Foreign Policy (New York: Random House, 1961). 